\title{
Walden Revisited \\ by Joyce Carol Oates
}

by

Monica Loeb

Västervil, Sweden

In 1854 Henry David Thoreau's second and last book appeared, entitled Walden or, Life in the Woods. It is an account of his personal experiences from living alone at Walden pond from July 4, 184.5 to September 6, 1847. This period of slightly more than two years has been compressed into one year in the book to provide unity which is further enhanced by the circle of the seasons that symbolically trace Thoreau's spiritual quest. His aim was to live close to nature in order to reduce life to its barest essentials: "I went to the woods because I wished to live deliberately, to front only the essential facts of life, and see if I could not learn what it had to teach, and not, when I came to die, discover that I had not lived." 1

The second chapter of Walden bears the title "Where I Lived, and What I Lived For" and does perform exactly what it promises. Thoreau proceeds to describe the site where he decided to build his simple house on Emerson's land, one and a half miles south of Concord, Massachusetts. He tells us of his fascination with the water of the pond where his daily morning bath is almost made into a sacred ritual. "Every morning was a cheerful invitation to make my life of equal simplicity, and I may say innocence, with Nature herself" (T., p. 64). He stresses the importance of man waking up, reawakening and keeping awake in order to affect the quality of his day or, rather, his entire life.

This naturally leads Thoreau onto the second part of his chapter heading: his reason for seeking solitude in the woods. "I wanted to live deep and suck out all the marrow of life, to live so sturdily and Spartan-like as to put to rout all that was not life, to cut a broad swath and shave close, to drive life into a corner, and reduce it to its lowest terms, and, if it proved to be mean, why then to get 
he whole and genuine meanness of it, and publish its meanness to he world; or if it were sublime, to know it by experience ..." T., p. 66) He calls for simplicity of life as a contrast to the hurlyourly of modern life. "Why should we live with such hurry and vaste of life?" (T., p. 67) In fact, he believes that children undertand reality better than adults who fail to see the sublime and ioble of the present.

One hundred and sixteen years after the publication of Walden, short story carrying the same title as chapter two, "Where I ived, and What I Lived For," appeared in the Virginia Quarterly Autumn 1970; later republished in the collection Marriages and infidelities). ${ }^{2}$ His author, Joyce Carol Oates, openly acknowledges er debt to Thoreau, as well as to other authors who have furnished er with other titles, such as "The Dead," "The Lady with the "et Dog," "The Metamorphosis," and "The Turn of the Screw." the feels her stories are "reimaginings of famous stories" meant o be autonomous short stories, yet "testaments of my love and xtreme devotion to these other writers; I imagine a kind of piritual 'marriage' between myself and them, or let's say our taimons' in the Yeatsian sense ..." "3

My aims in this paper are first, to make a comparison of these wo stories, and second, to see how and to what extent the conemporary writer has chosen to use the original story by Thoreau. On a first glance there are more contrasts than obvious similaries between the two stories. However, the simple fact remains hat both stories are about men, two men who are concerned rith the quality of life. Thoreau speaks of "the essential facts of fe" (T., p. 66), while Oates' protagonist enviously suspects that lose who are not on the run as he is himself are refined to "an ssence, an idea" (O., p. 319). Unfortunately he himself is unable $\supset$ achieve this, as we shall see. Still another similarity is more of curious fact, the date; July 4, the day of American independence. $t$ is the day mentioned by the ever-running, Oatesian hero and rat was of course the day Thoreau moved into his cabin on Walden ond. The implication of such a strategic choice of dates might be ze need to tie the individual to a historical and national frame of aference.

Aside from these similarities, the dissimilarities dominate. I rould even venture to claim that Joyce Carol Oates' version is a 1odern illustration of the hurried life which Thoreau warns gainst in Walden. It is the duty of a serious writer to be a witness 
of our time, a "prayerful witness," that absorbs and then articulates the various experiences of people. This was stated by Joyce Carol Oates in a lecture given in Stockholm in the spring of 1980. She then also expressed the contention that she happened to be a member of a "very troubled society." Hence the prevalence of a great amount of violence in her fiction, a fact which she is constantly being asked about everywhere, ""except for Detroit, Michigan."4

As a consequence, it is no surprise to find a distraught character contemplating violence at the center of Oates' "Where I Lived, and What I Lived For." The story opens with a nameless person running. The first five paragraphs all start with either "I ran" or "I was running." They are all short, the very first one merely composed of "I ran," but without a full stop. Physical details are given, such as shoe size, dirt path, sweat on the forehead, the date and the sudden rain shower. The runner questions in italics whether the rain will have the power to renew him. The fifth paragraph simply sums up: "T ran in a spasm of terror," once again ending without a full stop (O., p. 318).

The mood set in this first half page is one of desperate movement, a wish for renewal appropriately underlined by the short and jagged paragraphs, the repetition of crucial phrases and the frequent lack of full stops. In addition, there is added, as so often is the case in Oates, a note of mystery. "I was running and the sudden rain passed back to me, a moving cloud of light prickling rain, scattered and abrupt as his panic" (O., p. 318). Whose panic? we naturally ask and keep on asking as the pronouns "he" or "his" recur throughout the story. The reader must seek his own answers and explanations.

Gradually we find out more about the nameless running protagonist. For instance, he feels that he is imprisoned in his own body that serves as a cage, "my ribs a cage, and inside, my heart was pounding to be let out! to get free!" (O., p. 318) Although Thoreau also considers himself "caged" in relation to the birds around him, his imprisonment is not viewed as something negative but rather positive, since he is getting near to live birds in nature without imprisoning them (T., p. 62).

Oates' hero even eats on the run, suggestive of the hamburger joints and other quick-food stands so prevalent today. Savage with hunger, he feels as if "it was his body $\mathbb{I}$ had seized and was devouring, raw ..." (O., p. 319) We get a first glimpse of violent fantasy, involving "'him." The next piece of information we are 
fered is the fact that the runner is a father and has a wife. The mily lives in a small house where everyone keeps bumping into ach other. His wife's body is full of bruises, which we naturally nd to associate with their cramped home life (O., p. 320), but, page later, they are explained as injuries suffered on the beach hen she had been dragged along the rocky bottom by a huge we.

He is certainly not painting a favorable image of his wife: "I ould have reached into the back of her skull and come out with thing" (O., p. 320). He also senses that she wants to run," to in for her life away from me" (O., p. 320). His wishful thinking expressed in a whisper: "You can leave, you're free," but he too bound by convention to tell her that to her lace. A few zges later on, this wish is restated, once again in italics: "I $I$ should :ve been able to see it coming, obviously. A mental collapse. Cardiac rest. The end $\&$ a marriage" (O., p. 324). ,

Our hero is not merely tired of his marriage but he is tired of e in general: "I am so tired, so tired, it might be nearly over" J., p. 324). As a matter of fact, he has felt the end coming several mes, when he has been ready to give up, but has eventually sunced back "elastic and manly" to the surprise and pride of mily and friends. Then one day comes when you no longer feel re bouncing back, he explains, when you are "sick of being anly and brave" and actually wish to welcome the end. Then su whisper to yourself, "your old secret friend from boyhood: "ll right, that's it" (R., p. 325).

These last five words are to be repeated as his last sigh after ix careful strokes of the knife" begin to unpeel his skin (O., p. 5). This, in fact, is a repetition of his earlier fantasy of making $x$ incision at the top of "his" head, that time with "five or six rift precise strokes" before the total unpeeling of the person kes place, leaving the skin "down about his feet Like the pink sened useless petals of a flower" (O., p. 321).

$\mathrm{He}$ meets his end on a little hill out in nature. His last visual ipressions are of sand, clay and deep earth colors in strange id marvelous shapes. These shapes and colors all run together is if whispering their secret, their meaning" (O., p. 325). To e bitter end he is searching for some meaning. Re ends up king himself a long list of questions introduced by "why?" Why $\mathrm{d}$ his father not initiate him into the "snares and delights" of e? (O., p. 325) Why was his mother so selfish? Why were most 
things mysterious and disappointing to him? Why did he always reconstruct his own life, even "his own doubleness" (O., p. 326)? His final question, "Why had he been in such a hurry?" seems directly related to Thoreau's original query: "Why should we live with such hurry and waste of life?" (T., p. 67) In the more than one hundred years that have passed since Thoreau posed the question, man has not slowed down his life, but has rather accelerated it into a near frenzy.

Hypnotized by the shapes of earth, sand and clay on that hill, our modern nameless hero dies without having, or rather taking, the time to "make sense of it" (O., p. 326). Thoreau, by contrast, does exactly that and acquires a certain perspective on life. Joyce Carol Oates chooses to end her short story in the same frenzied, unpunctuated fashion that she started it:

"I am hypnotized -

He will die hypnotized -

I will die -"

It seems as if his life is running out into the sand on the hill where he is lying. It is interesting to note that the two final verbs are still in the future tense rather than the progressive form. There is no way of knowing whether he actually does commit suicide or whether he simply lives out his fantasy, as so many times before. What is important, however, is his feeling of an end to his life, of meaninglessness.

It is also worth noting that Oates' protagonist, as well as Thoreau, seek solace in nature. Thoreau removed himself entirely from urban life, actually choosing isolation (on his terms, for he did not abstain from social contacts with his friends) $)^{\mathbf{5}}$ and seeking closeness with nature. Just as Thoreau's morning bath in Walden Pond becomes a point of daily reinvigoration, Oates' man believes that rain water will have the power of renewing him. As a contrast to the tranquilly bathing Thoreau, the modern man is on the run, fanatically jogging, while hoping that the rain will renew him on the way, so to speak. He has missed the whole point of simplicity of life when he tries to kill two birds with the same stone.

The death scene also takes place in nature, on a small hill, rather than in the symbolically cramped house where he resides with his family. There is quite a lyrical description of nature on the hill: 
"Strange, marvelous shapes in the clay -.

flowing down the side of the hill, sand

of every degree of fineness, clay of a dark,

satiny, elegant texture, flowing downward

like lava - Little streams overlap and inter-

lace one another, flowing into the forms of sappy leaves or vines - I am seeing coral, I am seeing leopards' paws or birds' feet ..." (O., p. 325)

Here the tone changes. The dying man sees human organs in the apes of nature: "brains or lungs or bowels, and excrements of 1 kinds" (O., p. 325). The foliage turns "ancient," the colors orute" and are all smeared together. Nature turns against the oor man, as he feels he cannot grasp "their meaning," i.e., the eaning of everything running together on that hillside (O., p. 25). Thus, the meaning of existence escapes him to the very end. e then blames others, such as his parents, for keeping life's crets away from him. En the end, be finally reproaches himself $r$ failing to find a meaning in life.

This lack of meaning or substance seems reflected in the repetion of the word "ordinary." The hill of the final scene is "an dinary hill in the country" (O., p. 326). When his parents died, 3 had felt "'guilty relief," but showed "ordinary grief" to the xtside world (O., p. 323). His wife was "an ordinary woman" id he himself "an ordinary man" (O., p. 321). Everything in eir lives was "ordinary and domestic" until he became hunted $\checkmark$ his terror (O., p. 321). This terror, in a perverse way, provides citement and movement in his life, away from the fear of the dinary.

There is nothing "ordinary" in Thoreau's life close to nature. e feels that every morning is a gift to him, "a cheerful invitation" attain nature's simplicity (T., p. 64). Heavy emphasis is placed 1 being awake and staying awake. Thoreau believes that man is the power himself to affect the quality of his own life: "I low of no more encouraging fact than the unquestionable ability man to elevate his life by a conscious endeavor ... To affect e quality sf the day, that is the highest of arts" (T., p. 65). One iportant way of affecting each day is to reduce the number of :tails occupying much of our time: "Our life is frittered away $\checkmark$ detail" (T., p. 66). We end up living "meanly, like ants ... re pygmies we fight with cranes, "simply taking on too much for 
our capacity. If we are to survive "in the midst of this chopping sea of civilized life," Thoreau repeats his advice: "Simplicity, simplicity, simplicity!" (T., p. 66)

Oates' twentieth-century man is too caught up in his chase to hear Thoreau's call. He knows that he is seeking some better quality in life, but has become too enwrapped in the running itself, thus clouding his goal. He can sense that nature ought to rencw him. However, it is in the embrace of nature that he dies, while Thoreau has the ability to gain life-spirit irom closeness with nature. What signifies life for Thoreau, becomes death for modern man. The latter has simply not learnt to "affect the quality" of his day (T., p. 65).

The difference between the nineteenth-century and the twentieth-century man are distinctly reflected in the styles chosen for each piece of writing. While Thoreau's prose is charactcrized by easy-flowing, well-constructed sentences, short and long ones alternating, and an overall design that can be sensed in its unfolding, the Oates story moves, in contrast, by fits and starts. Her frantic style is characterized by unfinished sentences, lack of punctuation, one-sentence paragraphs, one- or two-word sentences, innumerable dashes and dots for unfinished thoughts, and a great amount of rhetorical questions which are frequently in italics. These two contrasting styles naturally reflect the respective mental states of the two protagonists.

In content as well as style, Oates' story is an illustration of the hurried, cursory, even schizophrenic, life which Thoreau repudiates. Joyce Carol Oates seems to have used Thoreau's chapter "Where I Lived, and What I Lived for" as a point $d$ 'appui for a story about a distraught modern man, on the run, bored in his marriage, seeking change or escape. When Jailing to find any meaning in life, or failing to "affect the quality of the day," as Thoreau would have said it, he puts an end to his life. This is a tragic statement by Joyce Carol Oates on modern life, the "troubled society" we live in, as she terms it. In her Stockholm lecture she expressed the belief "that the tragic is a very viable way of approaching the world" and that she possesses what she calls a strong "tragic inclination," i. e., the ability to depict or articulate tragedy deeply felt by others who are unable to express it in a literary way. She feels that in tragic literature one must "deal with human beings at extremes," which is where one can see their "capacity for courage or strength, the capacity for audacity 
and imagination."6 Through her nameless jogger, Oates expresses this "meanness" of life that twentieth-century man frequently senses, but which Thoreau challenged and did transcend into sublimity.

\section{NOTES}

1 Henry David Thoreau, Walden or, Life in the Woods and On the Duty \& Civil Disobedience (New York: New American Library, 1960), p. 66. Future references to this work will be placed within parentheses in the text preceded by $\mathrm{T}$.

2 Joyce Carol Oates, Marriages and Fidelities (New York: Fawcett Crest, 1972). Future references to this work will be placed within parentheses in the text preceded by $\mathrm{O}$.

3 Joe David Bellamy, The New Fiction, Interviews with Innovative American Writers (Chicago, Urbana, London, 1974), p. 22.

4 Joyce Carol Oates, Lecture at The American Center, Stockholm, June 2, 1980.

5 Walter Harding, $\boldsymbol{A}$ Thoreau Handbook (New York: Gotham Library, 1961), p. 65.

6 Joyce Carol Oates, Lecture at The American Center, Stockholm, June 2, 1980. 